\title{
ПОВРЗАНОСТА ПОМЕЃУ УСЛОВИТЕ ЗА ЖИВОТ ВО СЕМЕЈСТВОТО, УСПЕХОТ ВО УЧИЛИШТЕ И НЕПРИСПОСОБЕНОТО ОДНЕСУВАҢЕ КАЈ АДОЛЕСЦЕНТИТЕ
}

\section{Кратика сооржина}

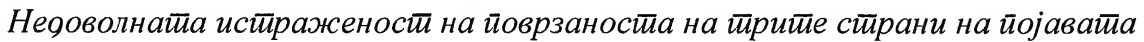
на нейрисйособено оянесување кај ученичиие - семејнииее факйори, усиехой во училишие и йојавайа на некој вио нейрисйособено оянесување беше основна иричина за gа ја истиражиме оваа иоојава. Посебен акиении во намейо истиражување е сииавен на сиечифичносиииие на йојавайа во неgоволно развиени среоини. Исииражувањейо е насочено кон ойкривање на иричинийе во семејсиивойо и йојавайа на нейрисйособено оянесуваюе кај аоолесиенииите на возрасии оя 13 gо 18 іооини. Исито йака, во исиражувањетио се обрнува внимание и на йоврзаносйа йомеїу йојавайа на нейрисиоособено оянесување и слабиой усйех на ученициие.

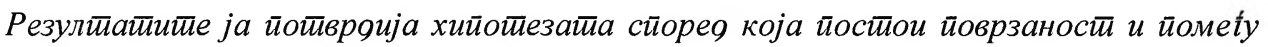
семејните факитори, усиехой во училишие и нейрисйособенойо оянесување кај аяолесченииите, ояносно аяолесценииите оя ироблемайични семејсиива и ученицииее со йослаб усиеех се со йовисок ризик яа йројавай некој вия нейрисйособено оянесување

$\begin{array}{lll}\text { Клучни зборови: } & \text { УСЛОВИ } 3 А \text { ЖИВОТ } & \text { ВО СЕМЕЛСТВОТО, } \\ & \text { УЧИЛИШЕН УСПЕХ, } & \text { НЕПРИЛАГОДЕНОТО } \\ & \text { ОДНЕСУВАЬЕ } & \end{array}$

\section{Вовеg}

Живееме во време на сериозни општествено-економски промени и различни социјални потреси. Сѐ повисоката стапка на невработеност, во која најголем дел од работоспособното население се млади, е значаен генератор на кризите во општеството и на зголемување на појавата на различни видови социопатолошки појави и зголемен број млади зафатени со овие проблеми. Причина за тоа е и ослабената функција на семејството, кое притиснато од економската криза, барајќи основни начини за преживување, го запоставува воспитувањето на децата и најчесто ги препушта на влијание на улицата. Влијанието на улицата се одразува на нивното однесување, како и на успехот во училиште. Негативните општествени трендови се одразуваат негативно и во образовниот процес. Незадоволството на наствниците од третманот што го имаат во општеството ги прави недоволно 
заинтересирани за работата и за воспитувањето на децата. Не се доволно ангажирани ни во однос на успехот, а особено во однос на однесувањето на учениците. Недоволно се интересираат за семејните услови на учениците, средината од каде што доаѓаат и често пати сосема погрешно реагираат на однесувањето на децата. На овој начин уште повеќе ја усложнуваат ситуацијата во која се нашло детето.

Tоа е често и причина зошто дел од учениците што имале примерно однесување одеднаш попуштаат со успехот и/или пројавуваат неприспособено однесување. Имајќи го предвид споменатото, неминовно се наметнува прашањето: колку семејните услови влијаат на успехот во училиште и како понискиот успех станува причина за појава на неприспособено однесување?

Секое од овие прашања посебно е испитувано од различен аспект, при што се разликуваат резултатите од истражувањата. Меѓутоа, поврзаноста и меѓусебното влијание на овие три фактора: условийе во семејсиивойо, слабиой усйех и нейрисйособенойо оөнесуаване не е истражувано досега. Посебно, вакви истражувања не се правени во помали рурални населби каде што животните проблеми се разликуваат од оние во големите градови. Досегашните истражувања ја испитуваат врската помеѓу негативните влијанија во големите градови и појавата на деликвенција кај младите. Во нив се истакнува дека големите градови овозможуваат полесно ширење на социопатолошки појави, а дека тоа не е случај во руралните средини. Недостатокот на ваков вид истражувања во мали урбани средини беше една од причините за определба за истражување на овие проблеми во мала приградска средина, во училиште со многу различен состав на ученици кои потекнуваат од различни семејства.

\section{Методологија на истражувањето}

Како што истакнавме, недоволната истраженост на поврзаноста на йритие стирани на појавата на неприспособено однесување кај учениците: семејните фактори, успехот во училиште и појавата на некој вид неприспособено однесување беше основна причина за да ја истражиме оваа појава. Посебен акцент во нашето истражување е ставен на специфичностите на појавата во недоволно развиени средини. Истражувањето е насочено кон откривање на причините во семејството и појавата на неприспособено однесување кај адолесцентите на возраст од 13 до 18 години. Исто така, во истражувањето се обрнува внимание и на поврзаноста помеѓ појавата на неприспособено однесување и слабиот успех на учениците.

Предмет на истражувањето е йоврзаносйа йомеі́у нейрисйособенойо оянесување, семејниие услови и усиехой во училишие кај аяолесцениииие

Варијабли на исииражувањейо:

- видови неприспособено однесување;

- успехот во училиште;

- семејствато и неговата структура;

- социоекономската полажба на семејството. 


\section{Хийойези}

\section{Ойщйа хийойеза}

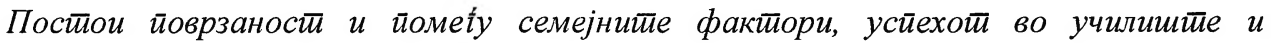
нейрисйособенойо оянесување кај аяолесиенииите: аяолесиенииите оя йроблемаиични семејсиива и учениииие со иоослаб усиех се со йовисок ризик qа иројавай некој вия нейрисйособено оянесуване.

\section{Посебни хийойези}

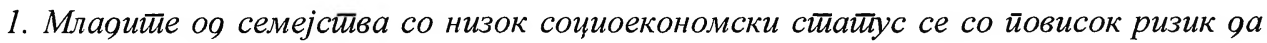
развијай некој вия нейрисиоссобено оянесување.

2. Наруиениие ояноси меіу членовиие во семејсиивойо се значаен факйор за йојава на нейрисйособено оянесување кај йомлаяииее членови во семејсиивойо.

3. Млаяите иито иотиекнуваай оя семејстива во кои йостиои член со асоиијално оянесување се со йовисок ризик яа ирројавай нейрисйсособено оянесување.

\section{Примерок на исииражувањет̄ио}

Во прелиминарното истражување беше употребен репрезентативен примерок од 108 (33\%) учениците на возраст од 13 до 16 години (од седмо и од осмо одделение). Во конкретниот стратификуван примерок на ова истражување беа земени само учениците кои покажуваат слаб успех во училиште и/или манифестираат облици на неприспособено однесување.

\section{Методи и техники}

Во истражувањето е користена комбинација од квантитативни и квалитативни методи и техники за собирање и обработка на податоците.

Од йехниките за сообирање йоgайоци беа користени:

- анкеиенн ирашалник; и

- неситрукитурирано иниетрвју со наситавнициие кои го извршиле изборот на ученици со неприспособено однесување.

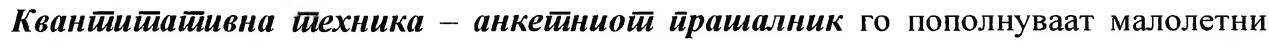
лица и е дизајниран за добивање слика за причините и видовите неприспособено однесување. Прашалникот претставува комбинација на прашања од отворен, полуотворен и затворен тип. 


\section{Техники за квалитайивна анализа, обработкка и йрикажување на йоgатиоцитее}

За обработка и прикажување на податоците се користи явоен семанииички өиференұијал. Како техника се користи за оцена на положбата на детето во семејството, т.е. односите помеѓу членовите на семејството и односите на детето со своите родители. Оваа техника овозможува да се уочи нивото на незадоволство, посакуваната положба - нивото на аспирација и разликата во нивото на незадоволство и нивото на аспирација, како и дисбаланс помеѓу овие две нивоа.

\section{Резултати и дискусија на резултатите}

Резултатите од истражувањето што ќ бидат предмет на обработка и интерпретација се однесуваат само за главниот примерок од 50 испитаници кои имаат послаб успех во училиште и кај кои се присутни различните видови неприспособено однесување.

\section{Генерален йриказ на вияовийе нейрисйособено/оеликвенйно оянесување}

На Табела 1 се прикажани најчестите видови неприспособено однесување кај децата со послаб успех во училиште.

\section{Табела 1: Вияови нейрисйособено оgнесување}

\begin{tabular}{|c|c|c|}
\hline Видови на неприспособено & \multicolumn{2}{|c|}{ Манифестирани } \\
\hline однесување & Број & Процент \\
\hline Бегање од часови & 31 & 32 \\
\hline Незаинтересираност за настава & 27 & 28 \\
\hline Пушење цигари & 16 & 16 \\
\hline Агресивност & 17 & 17 \\
\hline Конзумирање алкохол & 7 & 7 \\
\hline Вкупно: & 98 & 100 \\
\hline
\end{tabular}

Податоците од Табела 1 покажуваат дека најзастапена форма на неприспособено однесување е бегање од часови и тоа изразено во проценти изнесува $32 \%$ во однос на вкупниот број други видови. Незаинтересираност за настава е присутна кај 28\% од испитаниците. Другите видови се застапени со понизок процент, а сепак се значајно присути. Пушењето цигари е застапено кај $16 \%$ испитаници, агресивноста кај $17 \%$, а консумирањето алхохол кај 7\% испитаници.

Добиените резултати укажуваат на тоа дека децата кои бегаат од часови и не се заинтересирани за настава имаат слаб успех. Споредбата помеѓу бројот на ученици кои бегаат од часови и бројот на ученици кои се незаинтересирани за настава укажува на фактот дека најголем број од децата кај кои се присутни овие две форми на неприспособено однесување имаат и слаб успех. 


\section{Проверка на хипотезите и дискусија на резултатите}

Посебна хипотеза 1: Млаяийе оо семејсиива со низок соџиоекономски сйайус се со иовисок ризик яа развијай некој вия нейрисйособено оянесување

Социоекономскиот статус на семејствата е испитуван со помош на два индикатора: вработеност/невработеност на родителите и вкупни примања во семејството.

Врз основа на првиот индикатор се направени следниве групи:

- семејства во кои се вработени двајцата родители;

- семејства во кои е вработен само едниот родител; и

- семејства во кои двајцата родители се неврабтени.

Табела 2: Врабойености/неврабойеносй на рояийелийе и вияови нейрисйособено оонесување кај өецаша

\begin{tabular}{|c|c|c|c|c|c|c|}
\hline \multirow[b]{2}{*}{$\begin{array}{c}\text { Работен } \\
\text { статус на } \\
\text { родителите }\end{array}$} & \multicolumn{5}{|c|}{ Вияови нейрисйособено оянесувње } & \multirow[b]{2}{*}{ Вкупно: } \\
\hline & $\begin{array}{c}\text { Бегање } \\
\text { од } \\
\text { часови }\end{array}$ & $\begin{array}{c}\text { Незаинтересиран } \\
\text { за настава }\end{array}$ & $\begin{array}{c}\text { Пушење } \\
\text { цигари }\end{array}$ & Агресивност & $\begin{array}{c}\text { Консумирање } \\
\text { алхохол }\end{array}$ & \\
\hline $\begin{array}{c}\text { Вработен } \\
\text { еден } \\
\text { родител }\end{array}$ & $\begin{array}{c}11 \\
(11 \%)\end{array}$ & $\begin{array}{c}13 \\
(14 \%)\end{array}$ & $\begin{array}{c}4 \\
(4 \%)\end{array}$ & $\begin{array}{c}6 \\
4 \%\end{array}$ & 0 & $\begin{array}{c}34 \\
(35 \%)\end{array}$ \\
\hline $\begin{array}{l}\text { Вработени } \\
\text { двајцата } \\
\text { родители }\end{array}$ & $\begin{array}{c}3 \\
(4 \%)\end{array}$ & $\begin{array}{c}1 \\
(1 \%)\end{array}$ & $\begin{array}{c}2 \\
(2 \%)\end{array}$ & 0 & $\begin{array}{c}3 \\
(3 \%)\end{array}$ & $\begin{array}{c}8 \\
(9 \%)\end{array}$ \\
\hline Невработени & $\begin{array}{c}17 \\
(17 \%)\end{array}$ & $\begin{array}{c}13 \\
(13 \%)\end{array}$ & $\begin{array}{c}10 \\
(10 \%)\end{array}$ & $\begin{array}{c}11 \\
(11 \%)\end{array}$ & $\begin{array}{c}4 \\
(4 \%)\end{array}$ & $\begin{array}{c}55 \\
(56 \%)\end{array}$ \\
\hline Вкупно: & $\begin{array}{c}31 \\
(32 \%)\end{array}$ & $\begin{array}{c}27 \\
(\%)\end{array}$ & $\begin{array}{c}16 \\
(16 \%)\end{array}$ & $\begin{array}{c}17 \\
(17 \%)\end{array}$ & $\begin{array}{c}7 \\
(7 \%)\end{array}$ & $\begin{array}{c}98 \\
(100 \%)\end{array}$ \\
\hline
\end{tabular}

Кај семејствата во кои работат двајцата родители, појавата на деца со сериозни нарушувања во однесувањето е многу мал и изнесува $9 \%$. Кај семејствата во кои работи едниот родител е застапена кај $35 \%$ случаи; кај оние кај кои не работат двајцата процентот на деца со неприспособено однесување е значајно поголем и изнесува 56\% (Табела 2).

Пресметаниот Хи-квадрат тест кој изнесува $\chi^{2}=31,77$ и коефициентот на контингенција $\mathrm{c}=0,62$ упатуваат на заклучок дека постои поврзаност и зависност помеѓ вработеноста на родителите, како основен показател на социоекономскиот статус на семејството, и појавата на неприспособено однесување на децата. Добиените резултати се на ниво на статистичка значајност 0,01 . Односно, со голема сигурност можеме да ја потврдиме поврзаноста помеѓу овие два фактора. 
Табела 3: Материјална состојба на семејсшвото и вияовище нейрисйособен оонесување кај өецаша

\begin{tabular}{|c|c|c|c|c|c|c|}
\hline \multirow[b]{2}{*}{$\begin{array}{c}\text { Материјална } \\
\text { положба на } \\
\text { семејството }\end{array}$} & \multicolumn{5}{|c|}{ Вияови нейрисйособено оянесување } & \multirow[b]{2}{*}{ Вкупно: } \\
\hline & $\begin{array}{l}\text { Бегање } \\
\text { од } \\
\text { часови }\end{array}$ & $\begin{array}{c}\text { Незаинте- } \\
\text { ресираност } \\
\text { за настава }\end{array}$ & $\begin{array}{c}\text { Пушење } \\
\text { цигари }\end{array}$ & Агресивност & $\begin{array}{c}\text { Консуми- } \\
\text { рање } \\
\text { алхохол }\end{array}$ & \\
\hline $\begin{array}{c}\text { Незадоволи- } \\
\text { телна } \\
\text { (корисници на } \\
\text { соц. помош) }\end{array}$ & $\begin{array}{c}12 \\
(34 \%)\end{array}$ & $\begin{array}{c}13 \\
(37 \%)\end{array}$ & $\begin{array}{c}4 \\
(11 \%)\end{array}$ & $\begin{array}{c}6 \\
(19 \%)\end{array}$ & $\begin{array}{c}0 \\
(\%)\end{array}$ & $\begin{array}{c}35 \\
(100 \%)\end{array}$ \\
\hline $\begin{array}{c}\text { Задоволител- } \\
\text { на }\end{array}$ & $\begin{array}{c}12 \\
(33 \%)\end{array}$ & $\begin{array}{c}10 \\
(28 \%)\end{array}$ & $\begin{array}{c}5 \\
(19 \%)\end{array}$ & $\begin{array}{c}6 \\
(19 \%)\end{array}$ & $\begin{array}{c}3 \\
(8 \%)\end{array}$ & $\begin{array}{c}36 \\
(100 \%)\end{array}$ \\
\hline Добра & $\begin{array}{c}7 \\
(26 \%)\end{array}$ & $\begin{array}{c}4 \\
(11 \%)\end{array}$ & $\begin{array}{c}7 \\
(26 \%)\end{array}$ & $\begin{array}{c}5 \\
(17 \%)\end{array}$ & $\begin{array}{c}4 \\
(14 \%)\end{array}$ & $\begin{array}{c}27 \\
(100 \%)\end{array}$ \\
\hline Вкупно: & $\begin{array}{c}31 \\
(32 \%)\end{array}$ & $\begin{array}{c}27 \\
(28 \%)\end{array}$ & $\begin{array}{c}16 \\
(16 \%)\end{array}$ & $\begin{array}{c}17 \\
(17 \%)\end{array}$ & $\begin{array}{c}7 \\
(77 \%)\end{array}$ & $\begin{array}{c}98 \\
(100 \%)\end{array}$ \\
\hline
\end{tabular}

Вториот индикатор што ја покажува социоекономската положба на семејствата се месечните приходи според кои тие се поделени во следниве групи:

- семејства што се корисници на социјална помош (во оваа група спаѓаaт семејства во кои родителите се невработени и немаат никакви други примања);

- семејства со вкупни месечни приходи од 5.000 до 9.000 денари (задоволителна);

- семејстава со месечни примања над 10.000 денари (добра).

Анализата на податоците од Табела 3 покажа дека различни видови неприспособено однесување е присутно кај децата со слаб успех од семејства со различна материјалена состојба. Бегањето од часови е еднакво присутно кај децата од семејства со незадоволителна и со задоволителна материјална состојба - $34 \%$. Бегањето од часови е присутно и кај децата од семејства со добра материјална состојба - 26\%. Како надополнување на бегањето од часови се појавува следниов вид незадоволително однесување - незаинтересираност за настава, однесување кое е во тесна врска со бегањето од училиште, почесто присутно кај децата од семејства корисници на социјална помош $(37 \%)$ и кај деца од семејства со задоволителна материјална состојба (28\%). Најниска застапеност на овој вид неприспособено однесување има кај децата од семејства со добра материјална состојба - $11 \%$. Резултатите покажуваат дека двете форми на неприспособено однесување на децата се среќаваат почесто кај децата од семејства со незадоволителна материјална состојба.

Пушењейо како вид несоодветно однесување е најзастапено кај децата од семејства што имаат добра материјална полажба (26\%), потоа од семејства со задоволителна материјална положба (19\%) и малку понизок (11\%) кај децата од семејства со незадоволителна материјална положба. 
Аіресивнойо оонесување се јавува речиси еднакво кај децата од сите категории семејства, и тоа: од семејства со незадоволителна положба (19\%), кај децата од семејства со добра материјална состојба (17\%) и кај децата од семејства со задоволителна материјална состојба (19\%). Разликите не се статистички значајни.

Консумирањетио алкохол како вид несоодветно однесување се појавува ретко кај децата од семејства што имаат задоволителна материјална состојба $(8 \%)$, кај оние од семејства со добра материјална состојба е застапено со $14 \%$, а кај децата од семејства што имаат незадоволителна материјална состојба овој облик на однесување не се појавува кај ниту едно од нив. Можеме да претпоставиме дека ваквиот резултат веројатно се должи на тоа што пушењето цигари и консумирањето алкохол е поврзано со располагање со одредена сума пари, која децата од семејства со незадоволителна материјална состојба не ја поседуваат.

Генерално, од Табела 3 може да заклучиме дека нейоволнайа майеријална состиојба влијае врз йојавайа на нейрисйособено оянесување на яеиайа, и йоа: колку е ионейоволна майеријалнайа сосиојба на семејсивоиио, йолку е йоіолем ризикой оо йојава на некој вио нейрисйособено оянесување кај яечайа. Пресметаниот Хи-квадрат тест кој изнесува $X^{2}=21,36$ и коефициентот на контингенција $\mathrm{c}=0,32$ покажаа постоење на значајност на разлики во зачестеноста на различните видови неприспособено однесување меѓу децата од семејства со различен материјален статус. Значајноста на разликите е на ниво 0,05 . Бидејќи разликите помеѓу групите семејства се статистички значајни, може да ја потврдиме врската помеѓу материјалната положба на семејството и појавата на неприспособено однесување кај децата.

Појавата на статистички значајни разлики во бројот и видовите неприспособено однесување кај децата од семејства со различен статус на вработеност на родителите и со различен материјален статус на семејството (Табела 2 и Табела 3) покажаа дека појавата на различни видови неприспособено однесување е почеста кај децата од семејства со низок социоекономски статус во однос на оние од семејстава со добар статус. Тоа значи дека социоекономскиот статус на семејството претставува значаен ризик-фактор за појава на неприспособено однесување на децата од тие семејства.

Од табелите 1, 2 и 3 може да заклучиме дека младите кои потекнуваат од семејства со низок социоекономски статус се со повисок ризик да развијат некој вид неприспособено однесување во однос на оние од семејства со добар социоекономски статус. Добиените резултати во целост ја потврдија поединечната хипотеза 1. 
Посебна хипотеза 2: Нарушенийе ояноси мећ́ членовийе во семејсйвойо се значаен факӣор за йојавайа на нейрисйособено оянесување кај йомлаоиие членови во семејсйвойо. Влијанието на односите во семејството на појавата на неприспособено однесување кај децата го испитувавме преку:

- анализа на односите на децата со родителите и семејството и видовите неприспособено однесување кај децата;

- анализа на односите во семејството општо помеѓу сите членови и појавата на неприспособено однесување кај помладите членови - децата.

Во двете анализи групирањето на семејствата е направено според следниве категории односи:

- семејства во кои односите меѓу децата и родителите/меѓу сите членови се слаби со минимални комуникации;

- семејства во кои односите меѓу децата и родителите/меѓу сите членови се лоши;

- семејства во кои односите меѓу децата и родителите/меѓу сите членови се добри;

и

- семејства во кои односите меѓу децата и родителите/меѓу сите членови се одлични.

Табела 4: Семејнитее оgноси/ояноси на оецайа со роgийелитие и вияовийе нейрисйособено оянесување

\begin{tabular}{|c|c|c|c|c|c|c|}
\hline \multirow[b]{2}{*}{$\begin{array}{c}\text { Односи со } \\
\text { родителите }\end{array}$} & \multicolumn{5}{|c|}{ Вияови нейрисйособено оянесување } & \multirow[b]{2}{*}{ Вкупно: } \\
\hline & $\begin{array}{c}\text { Бегање од } \\
\text { часови }\end{array}$ & $\begin{array}{c}\text { Незаинтереси- } \\
\text { раност } 3 а \\
\text { настава }\end{array}$ & $\begin{array}{c}\text { Пушење } \\
\text { цигари }\end{array}$ & Агресивност & $\begin{array}{c}\text { Консумирање } \\
\text { алхохол }\end{array}$ & \\
\hline Слаби & $\begin{array}{c}11 \\
(35 \%)\end{array}$ & $\begin{array}{c}11 \\
(41 \%)\end{array}$ & $\begin{array}{c}6 \\
(38 \%)\end{array}$ & $\begin{array}{c}7 \\
(42 \%)\end{array}$ & $\begin{array}{c}3 \\
(44 \%)\end{array}$ & $\begin{array}{c}38 \\
(39 \%)\end{array}$ \\
\hline Лоши & $\begin{array}{c}9 \\
(29 \%)\end{array}$ & $\begin{array}{c}9 \\
(33 \%)\end{array}$ & $\begin{array}{c}4 \\
(25 \%)\end{array}$ & $\begin{array}{c}5 \\
(29 \%)\end{array}$ & $\begin{array}{c}2 \\
(28 \%)\end{array}$ & $\begin{array}{c}29 \\
(30 \%)\end{array}$ \\
\hline Добри & $\begin{array}{c}10 \\
(32 \%) \\
\end{array}$ & $\begin{array}{c}7 \\
(26 \%) \\
\end{array}$ & $\begin{array}{c}4 \\
(25 \%) \\
\end{array}$ & $\begin{array}{c}5 \\
(29 \%) \\
\end{array}$ & $\begin{array}{c}2 \\
(28 \%) \\
\end{array}$ & $\begin{array}{c}28 \\
(29 \%) \\
\end{array}$ \\
\hline Одлични & $\begin{array}{c}1 \\
(4 \%)\end{array}$ & $\begin{array}{c}0 \\
(\%)\end{array}$ & $\begin{array}{c}2 \\
(12 \%)\end{array}$ & 0 & 0 & $\begin{array}{c}3 \\
(2 \%)\end{array}$ \\
\hline Вкупно: & $\begin{array}{c}31 \\
(100 \%)\end{array}$ & $\begin{array}{c}27 \\
(100 \%)\end{array}$ & $\begin{array}{c}16 \\
(100 \%)\end{array}$ & $\begin{array}{c}17 \\
(100 \%)\end{array}$ & $\begin{array}{c}7 \\
(100 \%)\end{array}$ & $\begin{array}{c}98 \\
(100 \%)\end{array}$ \\
\hline
\end{tabular}

Анализата на подетоците од Табела 4 покажа:

- Беіаъейо og часови е застапено кај 64\% од децата кои имаат слаби (минимални) односи со родителите или имаат лоши односи. Истиот вид неприспособено однесување се среќава кај значително помал процент кај децата кои имаат добри и особено одлични односи со родителите и изнесува $36 \%$;

- Незаинйересираносй за насйава е многу почест кај децата од семејства во кои односите родител - дете се лабави или минимални или се лоши и изнесува $74 \%$ од целата група. Процентот на деца кои се незаинтересирани за настава, а кои имаат добри односи со 
родителите е помал и изнесува $26 \%$. Интересно е да се истакне дека од семејства кај кои постојат одлични односи помеѓу децата и родителите нема деца кај кои се јавува овој вид неприспособено однесување;

- Пушењейо ииіари како трет вид несоодветно однесување е присутно кај $63 \%$ од децата чиишто врски со родителите се слаби и особено лоши. Овој вид однесување е присутно кај $37 \%$ од децата со добри и со одлични односи со родителите;

- Аіресивнойо оянесуваъе, исто така, најчесто е застапено кај децата кои имаат слаби односи со родителите или имаат лоши односи и изнесува $71 \%$. Овој вид неприспособено однесување се среќава кај $29 \%$ кај децата со добри односи со своите родители. Кај децата кои имаат одлични односи со своите родители нема ниедно дете со овој вид однесување;

- Консумирањетио алкохол е присутно кај $72 \%$ од децата кои имаат слаби или лоши односи со своите родители. Овој вид неприспособено однесување се среќава кај $28 \%$ од децата кои имаат добри односи со родителите. Треба да истакнеме дека и овде како и во претходниот случај кај децата кои се во одлични односи со своите родители нема ниедно дете со овој вид неприспособено однесување.

Од податоците изнесени во Табела 4 може да заклучиме: недоволните, а особено лошите односи помеѓу децата и нивните родители резултираат со појава на голем број различни видови неприспособено однесување.

Презентираните податоци во Табела 4 покажуваат дека нарушениие ояноси йомеty geчай и нивниие рояииели се битина иричина за йојава на нейрисиособено оянесување на gечайа. Односно, децата кои имаат лоши односи со своите родители се со висок ризик од појава на неприспособено однесување.

Добиените резултати од Табела 4 ја потврдија посебната хипотеза 2, која гласи: нарушениие ояноси меtу членовиие во семејсиввойо се значаен факйор за йојава на нейрисйособено оянесување кај йомлаяиие членови во семејсиивойо.

Посебна хипотеза 3: Млаяиие шито ииоиеекнуваай оя семејстива во кои има член со асоиијално оянесување се со йовисок ризик яа иіројавай нейрисйособено оонесување.

Како најчести форми на асоцијално однесување што се среќаваат во семејствата се: алкохолизам, наркоманија, насилничко однесување, криминално однесување и др. 
Табела 5: Семејстива шито имаат/немаати член/ови со асоцијално оянесување и вияовите нейрисйособено оянесување кај фецайа

\begin{tabular}{|c|c|c|c|c|c|c|}
\hline \multirow[b]{2}{*}{ Семејство } & \multicolumn{5}{|c|}{ Видови неприспособено однесување } & \multirow[b]{2}{*}{ Вкупно: } \\
\hline & $\begin{array}{c}\text { Бегање } \\
\text { од } \\
\text { часови }\end{array}$ & $\begin{array}{c}\text { Незаинтере- } \\
\text { сираност за } \\
\text { настава }\end{array}$ & $\begin{array}{c}\text { Пушење } \\
\text { цигари }\end{array}$ & $\begin{array}{c}\text { Консумирање } \\
\text { алкохол }\end{array}$ & Агресивност & \\
\hline $\begin{array}{l}\text { Има член } \\
\text { со асоци- } \\
\text { јално од- } \\
\text { несување }\end{array}$ & $\begin{array}{c}19 \\
(20 \%)\end{array}$ & $\begin{array}{c}15 \\
(15 \%)\end{array}$ & $\begin{array}{c}11 \\
(11 \%)\end{array}$ & $\begin{array}{c}8 \\
(8 \%)\end{array}$ & $\begin{array}{c}5 \\
(5 \%)\end{array}$ & $\begin{array}{c}58 \\
(59 \%)\end{array}$ \\
\hline $\begin{array}{c}\text { Нема член } \\
\text { со асоци- } \\
\text { јално од- } \\
\text { несување }\end{array}$ & $\begin{array}{c}12 \\
(12 \%)\end{array}$ & $\begin{array}{c}12 \\
(12 \%)\end{array}$ & $\begin{array}{c}5 \\
(5 \%)\end{array}$ & $\begin{array}{c}9 \\
(9 \%)\end{array}$ & $\begin{array}{c}2 \\
(2 \%)\end{array}$ & $\begin{array}{c}40 \\
(41 \%)\end{array}$ \\
\hline Вкупно: & $\begin{array}{c}31 \\
(32 \%)\end{array}$ & $\begin{array}{c}27 \\
(28 \%)\end{array}$ & $\begin{array}{c}16 \\
(16 \%)\end{array}$ & $\begin{array}{c}17 \\
(17 \%)\end{array}$ & $\begin{array}{c}7 \\
(7 \%)\end{array}$ & $\begin{array}{c}98 \\
(100 \%)\end{array}$ \\
\hline
\end{tabular}

Податоците од Табела 5 покажуваат дека децата што потекнуваат од семејства во кои некој од членовите има некаков вид асоцијално однесување се со поголем ризик да развијат неприспособено однесување. Тоа го покажува процентот на деца од овие семејства $(59 \%)$ кај кои се појавило неприспособено однесување.

Децата што потекнуваат од семејства во кои има член/ови со асоцијално однесување ги манифестираат следниве форми на неприспособено однесување:

- беiање оg часови како форма на неприспособено однесување се јавува кај речиси $20 \%$ од децата од овие семејства;

- незаинйересираности за насйава е појава која се среќава кај 15\% од децата;

- йушење чиіари се јавува кај $11 \%$ од децата;

- консумирање алкохол се среќава кај $8 \%$ од децата;

- аіресивно оянесување е присутно кај 5\% од децата.

Сепак, не е мал процентот и на деца со некој вид неприспособено однесување и од семејствата во кои нема член со асоцијално однесување (41\%).

Децата од семејствата во кои нема член со асоцијално однесување ги манифестираат следниве форми на неприспособено однесување:

- беїање оя часови се среќава кај $12 \%$ од децата од семејства во кои нема член со асоцијално однесување;

- незаинйересираносии за насйава се среќава кај ист број деца - $12 \%$;

- иушење чиіари кај 5\% од децата од овие семејства;

- консумирање алкохол кај 9\% од децата; и

- аіресивно оонесување само кај $2 \%$ од децата. 
За појасно увидување на разликите во бројот и видовите неприспособено однесување кај децата од семејствта во кои има членови со асоцијално однесување и од оние во кои нема, беше применет Пирсоновиот коефициент на контингенција кој изнесува 0,83 со коефициент на детерминација 0,64 што ја докажува статистичката значајност во бројот и видовите неприспособено однесување кај децата од семејства со и без член/ови со асоцијално поведение. Бидејќи значајноста е на ниво 0,05 може да заклучиме дека покрај влијанието на овој фактор на појава на неприспособено однесување, кај децата влијаат и други значајни фактори во семејството, пред сѐ, материјалната состојба и особено нарушените односи во семејството.

Преку потврдата на посебните хипотези ја потврдивме и општата хипотеза:

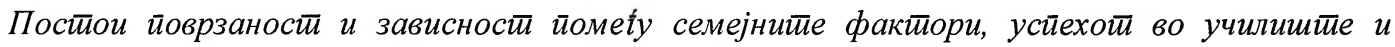
нейрисйособенойо оянесување кај аяолесченииите; аяолесченииите оя йроблемаиични семејсиива и ученичиие со йослаб усиех се со йовисок ризик gа иројавай некој вия яеликвенйно оянесување.

\section{Заклучок}

Длабоките промени во општеството негативно влијаат на децата и младите врз нивната социјализација и на семејството во извршувањето на неговите функции.

Немањето систем на вредности се огледува во барање смисла на животот во деструктивно, асоцијално однесување, вандализам, себичност, препуштање на нагонски побуди, злоупотреба на дроги и алкохол, секс и уживање, самоволие, насилство и криминал. Тоа се последиците од воспитувањето без вредности. Ризичните фактори се карактеристики, варијабли или опасности кои поединците или групите, ако ги поседуваат, лесно ќе предизвикаат развој на различни нарушувања повеќе отколку кај други поединци или групи во општата популација. Ризиците се групираат во: биолошки; психолошки и социјални фактори што влијаат во индивидуалното, семејното или срединското опкружување. Во нашето истражување во целиот примерок немаше испитаник со деликвентно однесување дефинирано според најтесното сфаќање според кое овој поим ги опфаќа само поведенијата пропишани како казнени дела. Поведенијата што се констатирани кај нашиот примерок се дефинирани со најширокиот поим на терминот малолетничка деликвенција, кој ги опфаќа и развојната запуштеност и неприспособеност на малолетникот или, со други зборови, различни предделиквентни состојби на личноста. Прифаќајќ ја оваа дефиниција, во нашето истражување ги употребуваме двата термина како синоними: неприспособено однесување и малолетничка деликвенција, што го поврзавме со слабиот успех во училиште.

\section{Препораки}

Земајки ги предвид сите сложени ризици што покриваат голем простор на ризични фактори на кои се изложени младите луѓе денес, а особено оние со ризик, превенцијата треба да биде фокусирана на многу различни фактори ако сакаме да постигнеме успех во 
намалувањето на појавата и бројот на деца и млади со нарушено однесување и тоа од неприспособено до деликвентно, девијантно, па дури и криминално однесување.

Моделите на редукција на ризикот од нарушување на однесувањето кај децата и младите кои се основа на секоја превенција мора да содржат програми што ќе се спроведуваат во училиштата, но и програми во кои ќе се вклучи и семејството, како и соодветните служби во локалната заедница. Програмите за препознавање на учениците со ризик (особено со ризик во семејството или ризичните групи во училиште) треба да се вклучат во рамките на часовите за проектни активности. За таа цел е неопходна и додатна едукација на наставниците, а особено на стручните служби во училиштето - психолозите и педагозите, кои ќе се занимаваат со превенција во училиштето. Социјалниот работник како најдобар познавач на семејството и ризичните фактори во семејството е и најсоодветен за превенирање на влијанието на овие фактори. Имајќи го предвид тоа, сметаме дека вработувањето социјални работници во училиштата се наметнува како неопходност. 


\section{Литература}

Astone N. \& McLanahan S., (1991). Family Structure, Parental Practices and High School Completion. American Sociological Review 56 : 309-20.

Bouck, E. C. (2007). Co-Teaching... Not Just a Textbook Term: Implications for Practice. Preventing School Failure, 51(2), 46-51. Retrieved from EBSCOhost.

Friend, M., Cook, L., Hurley-Chamberlain, D., \& Shamberger, C. (2010). Co-Teaching: An illustration of the complexity of collaboration in special education. Journal of Educational \& Psychological Consultation, 20(1), 9-27.

Burgess R., (1979). Family Violence: Implications from Evolutionary Biology. Pp. 91-101 In nderstanding Crime, edited by Travis Hirschi. Beverly Hills, CA: Sage Publications.

Canter R., (1982). Sex Differences in Self-Report Delinquency. Criminology. 20 : 373-93.

Chilton R. \& Markle G. (1972). Family Disruption, Delinquent Conduct, and the Effect of Subclassification. American Sociological Review. 37 : 93-99.

Cohen A. (1955). Delinquent Boys. Glencoe, IL: Free Press.Dusek J. B., (1987). Adolescent Development and Behavior. Englewood Cliffs, NJ: Prentice-Hall.

Eckert P. (1989). Jocks and Burnouts: Social Categories and Identity in High School. New York:Teachers College Press.

Elam S., Rose L., \& Gallup A., (1993). "Twenty-Fifth Annual Gallup Poll of the Public'sAttitude Toward Education." Phi Delta Kappan. 75 : 137-57.

Elliott D., Huizinga D., \& Ageton S., (1985). Explaining Delinquency and Drug Use. BeverlyHills, CA: Sage Publications

Giangreco, M. F., Suter, J. C., \& Doyle, M. (2010). Paraprofessionals in inclusive schools: A review of recent research. Journal of Educational \& Psychological Consultation, 20(1), 41-57

Niesyn, M. E. (2009). Strategies for success: Evidence-based instructional practices for students with emotional and behavioral disorders. Preventing School Failure, 53(4), 227-234. Retrieved from EBSCOhost.

Vannest, K. J., Temple-Harvey, K. K., \& Mason, B. A. (2009). Adequate yearly progress for students with emotional and behavioral disorders through research-based practices. Preventing School Failure, 53(2), 73-84. Retrieved from EBSCOhost. 
Sofija GEORGIEVSKA

\section{THE RELATIONSHIP BETWEEN LIVING CONDITIONS IN THE FAMILY, SUCCESS IN SCHOOL AND INAPPROPRIATE BEHAVIOR IN ADOLESCENTS}

\section{Summary}

Insufficient exploration of the relationship of inappropriate behavior among students: family factors, school performance and appearance of some sort of inappropriate behavior, was the main reason to explore this phenomenon. Special emphasis in our research is on the specifics of the appearance in rural areas. The research is aimed at discovering the causes of the family and appearance of inappropriate behavior among adolescents aged 13 to 18 years. Also, the study draws attention to the relationship between the occurrence of inappropriate behavior and poor school performance.

The results confirmed the hypothesis according to which there is a connection between family factors, school performance and inappropriate behavior adolescents or adolescents from troubled families, and underachieving students are at higher risk of exhibiting some sort of inappropriate behavior.

Keywords: FAMILY FACTORS, SCHOOL PERFORMANCE, INAPPROPRIATE BEHAVIOR 